УДК 821.163.41-32.09 Станковић, Борисав https://doi.org/10.18485/godisnjak.2020.15.11

Ана Д. Козић*

Универзитет у Београду

Филолошки факултет, докторанд
Оригинални научни рад

Примљен: 15. 09. 2020.

Прихваћен: 10. 11. 2020.

\title{
ЗАБРАНА И ЕРОС У ПРИПОВЕЦИ „СТОЈАНКЕ, БЕЛА ВРАЬАНКЕ” БОРИСАВА СТАНКОВИЋА
}

\begin{abstract}
Рад пружа еротолошко читање приповетке „Стојанке, бела Врањанке” Борисава Станковића. У фокусу се налази еротска љубав, при чему се: 1. осветљава однос између еротизма и забране (уз ослањање на магнетску теорију љубави о којој пише Ј. Евола); 2. тумачи веза између љубави и насиља у тексту; 3. издваја простор ослобођеног ероса кроз дозвољени додир у самоћи (аутоеротика) и кроз звук (музика и песма). Посматрајући сложени и динамички однос између забране и ероса у овој приповеци, тумаче се унутрашња превирања главних јунака и њихова карактеризација. Посебна пажња посвећена је издвајању и интерпретацији уметничких средстава, којима се уводи, описује и испољава еротско у књижевном тексту.
\end{abstract} догађај.

Кључне речи: ерос, танатос, забрана, Борисав Станковић, еротски

Приповетка „Стојанке, бела Врањанке” посебна је по више основа: (1) једна је од малобројних приповедака у којој се именује Врање, варош у коју је Станковић сместио радњу безмало свих својих књижевних остварења; (2) иако главна тема дела представља опште место - забрањену љубав између припадника две вере - љубав између Шаћира и Стојанке у овој приповеци наилази не само на конфесионалне и етичке препреке, већ и на оне које се тичу унутрашњих превирања јунака, па се тако потире

*ana.kozic@hotmail.com 
свака могућност клишетираности. У знаку Станковићеве поетике ова приповетка говори о сложеним породичним односима, издвајајући тренутак удаје/женидбе јунака као гранични тренутак у животу, осликава колебања јунака између поштовања и кршења колективних и индивидуалних забрана и указује на деструктивност потиснутог ероса.

\section{Магнетска привлачност забрањеног}

Већ на самом почетку приповетке успостављају се социјалне и верске разлике између главних јунака. Описивање групе радника који пролазе путем што води из Собине, погнутих глава и прописаним редоследом (мушкарци, девојке, па старије жене) упућује на уређеност и строгост у поштовању правила понашања, а у складу са тим и на свест о забранама, које су основ варошке средине Станковићевог Врања. Након овако кратке и једноставне назнаке уређености и конзервативизма средине у причу се уводи ерос са појављивањем главне јунакиње, која се из групе издваја лепотом и ходом пуним „господства и нежности”.

Стојанка представља прототип лепоте девојке из лирских народних песама: дугачка црна коса скупљена у плетеницу, мала црвена уста, бело лице, дуге трепавице, крупне и оборене црне очи. У опису доминирају фолклорни елементи, призивајући слику из познате народне лирске песме „У Милице дуге трепавице”, а уста „набубрела као трњине” наговештавају еротску привлачност којом Стојанка зрачи. ${ }^{1}$ Њен физички изглед описује се још једном у приповеци, али други пут из угла Шаћир-бега - онако како је он, из свог еротског бића, види и посматра:

Наслонивши главу на длан, упре поглед на Стојанку која одмицаше... Гледаше гојна округла плећа, курјуке косе како се, обасјани сунчаним зрацима, вију и преливају, шалваре како се као вал дижу и спуштају према ходу... Гуташе је погледом. Зажели се юе, ње! Њена бела лица, црних очију, лепих, једрих груди... Ах!... ноге му клецнуше (Станковић 2014: 24-25, курзив А. К.).

Опис тела вољене особе и утисак који оно оставља на заљубљеног представљају неизбежан део испољавања ероса у књижевном тексту. У складу са тим, и у овој приповеци описује се женско тело које је по-

\footnotetext{
${ }^{1}$ Женске усне имају изразиту еротску привлачност и њима се често наговештава еротски живот и потенцијал женског бића. Уста се често пореде са воћем, чиме се сугеришу сласт, мекоћа и влажност као основни женски принципи. У складу са тим и страст коју Андрићев Бајрон у приповеци „Бајрон у Синтри” осећа према лепој Португалки манифестује се у самом опису њених усана - оне су попут „распукле воћке” (Андрић 1981: 244) и наговештавају врелу крв која тече њеним крвотоком. Тако су и „навек румене и влажне усне” (Станковић 2004: 195) у Нечистој крви знак Софкиног ероса и једино што остаје од њене некадашње лепоте и жара.
} 
сматрано, које се удваја у погледу мушкарца обузетог жељом. Функција другог описа лепе Врањанке јесте управо у томе да покаже како се буди жеља у Шаћир-бегу. То је дескрипција Стојанкине телесности, а не само њеног тела, у оном смислу у којем Михаил Епштејн (2010: 50) говори о разлици између тела и телесности. Тело подразумева фигуру, тактилну и видљиву форму, док се телесност „састоји од влажности, глаткоће, топлоте, кривина - свега онога што ми перципирамо као оно што нас додирује и мази" (Исто: 50). ${ }^{2}$ Стојанкина телесност, коју бег слути и жели да открије, манифестује се у преливању њене косе док хода, затим у доживљају њене одеће која доприноси његовој еротској имагинацији - шалваре се крећу попут валова, дотичући, милујући њено тело при ходу и сведочећи о облинама и снази коју прикривају. ${ }^{3}$ Бег је гута погледом са жељом да се у потпуности смањи растојање између њих и у том посматрању жеља постаје све јача, а искушење све веће, чула се умногостручавају, а силина доживљаја исцрпљује снагу јунака.

Стојанка није неосетљива на овакве бегове жеље. О снази ероса који се у њој буди сведочи говор њеног тела - страх и ерос су испреплетани у њој и манифестују се кроз дрхтаје и језу која је обузима када се бег приближава. Доживљај страха и доживљај страсти за Стојанку су повезани и слични. Знак еротске напетости одражава се и у убрзаном ходу којем Стојанка прибегава када се приближава серају Шаћир-бега. Она убрзава јер се плаши себе, па се у овом гесту открива постављена сексуална забрана и страх од њеног преступа, али и неодољива привлачност коју забрањено носи са собом.

С обзиром на растућу жељу, коју оба јунака осећају, њихови сусрети представљају еротске догађаје, „еротеме”, ${ }_{4}^{4}$ иако ни у једном тренутку не долази до правог љубавног додира између њих. Ерос настаје и осећа се као својеврсна енергија која се буди и прожима их када су заједно, што је у складу са магнетском теоријом љубави о којој пише Јулијус Евола. ${ }^{5}$

\footnotetext{
${ }^{2}$ „Ми познајемо тело, видели смо га на дневном светлу - али ми га још увек нисмо упознали у својој телесности. То телесно знање се формира у тами, оно се састоји од укуса, мириса, додира" (Епштејн 2010: 50).

${ }^{3}$ „Жеља, еротска машта, еротска видовитост пролазе кроз тела, чине их провидним. Или их уништавају. С ону страну тебе, с ону страну мене, телом у телу, с ону страну тела, хоћемо да видимо нешто. То нешто је еротска фасцинација, оно што ме извлачи из мене самога и носи ка теби: оно што ме тера да идем с ону страну тебе" (Пас 1982: 65).

${ }^{4}$ Еротема представља термин Михаила Епштејна (2010: 45), који он дефинише у књизи Sola amore: „Еротема представља еротски догађај, јединицу осећајног преживљавања и деловања, оно из чега се састоји динамика, сиже еротских односа".

${ }^{5}$ У књизи Метафизика секса Евола (1990: 33) истиче: „Као што се досад видело, ни биолошка теологија, ни генетички импулс, ни одвојена идеја задовољства као циља не
} 
Позивајући се на традиционална далекоисточна учења, Евола (1990: 34) говори о посебној енергији (флуиду), која се буди у бићу кад је у присуству вољене особе и која се зове тсинг. ${ }^{6}$ Тсинг представља специфичност виталне снаге $т с р и$ која расте у складу са сексуалношћу мушкарца и жене и која се манифестује као вибрација и дифузна опијеност (Исто: 34): „Наћи се заједно сами, мушкарац пред женом, чак и ако не дође до додира, исто је као да је до њега дошло. Подлога тога позива се управо на основни магнетизам, на први степен буђења снаге тсинг" (Исто: 34). Управо то је случај са првим сусретом Стојанке и бега - вибрације ероса осећају се у ваздуху, погледом се шаљу дрхтаји у тело, еротска имагинација се буди заједно са сексуалном енергијом која гуши јунаке, а посебно Шаћира.

Када бег сретне Стојанку крај чесме као изговор да јој се обрати тражи од ње да му наточи воде. Док му пружа тепсију, коју бег механички преузима и приноси устима, он посматра њено лице и груди. У приповеци пише да му је поглед „утонуо у” њено лице и груди, чиме се сугерише дубина и улазак. На овај начин дочарава се осећање унутрашњости, топлоте и нежности њених груди са жељом за њиховим миловањем, али и са жељом за упијањем и продирањем у њу саму, на шта сугестивно указују и глагол „утонути” и предлог ,у”. ${ }^{7}$ Бег бива толико обузет жељом да заборавља да пије воду, али успева да се загрцне и уплаши од силине сопствених осећаја:

И пружи му тестију. Он је узе, принесе устима, али заборави да пије. Поглед му утону у њено лице, груди. Загрцну, рука му задрхта и умал’ што не испусти тепсију. Са запламтелим лицем, сјајним очима, сав тресући се, пружи јој натраг тестију.

На, изгоре ме! - рече загушеним гласом, па се наже над њом сав цептећи као прут (Станковић 2014: 26).

Није бега овде изгорела вода, већ опредмећена еротска енергија Стојанкина еротска енергија која се прелила у тепсију са водом. Еротски дрхтаји и ватра шире се његовим телом, те он „цепти” као прут, па се на

објашњавају ерос. С оне стране свега овога, он треба да буде схваћен као стање непосредно одређено поларитетом полова, на исти начин као што присуство једног позитивног пола и једног негативног пола одређује магнетску појаву и све скупа има однос са магнетским пољем.”

${ }_{6}^{6}$ „Флуидно стање, снага тсинг из кинеског учења, прво се пали, преко погледа, а затим прожима крв. Од тог тренутка, заљубљени на неки начин носи у сопственој крви љубљену жену, и супротно, без обзира на удаљеност која евентуално може да их раздваја" (Исто: 36). На сличан начин и у овој приповеци, ерос је пробуђен код Шаћира преко погледа, а затим прожима његову крв („крв се угреја”) и та жеља за Стојанком не попушта ни након њеног убиства.

${ }^{7}$ Михаил Епштејн (2010: 147) пише управо о значају предлога „у” за љубав и љубавнике: „(...) љубав ово 'у' представља не као статичко 'где', већ као динамичко 'куда', енергију страсти. Љубавник жели да буде унутар вољене и истовремено да га она обузме и затвори унутар себе - да га окружи собом окружујући себе." 
овај начин манифестује енергија тсри о којој пише Евола. Оба љубавника својим телом осећају еротску енергију која се између њих протеже иако се стварни додир није реализовао. Од таквог додира Стојанка готово панично бежи, плашећи се да би могла да прекрши постављену забрану.

Забрана коју она осећа двострука је - на колективном плану то је неприхватљиво због религијских и социјалних разлика, а на интимном плану рађа се страх од понављања несрећне породичне историје. Након сусрета са бегом, Стојанка одлази код сестре, „Туркиње Ташане”, чиме се унапред, у само једној речи, одређује судбина њене сестре и наговештава њена исповест. Одлазећи код Ташане, која је већ прекршила забрану у прошлости и удала се за Турчина, Стојанка покушава да пронађе решење за сопствену ситуацију. О томе колико је забрана јака сведочи и чињеница да Стојанка ни у једном тренутку не признаје да воли Шаћира, јер се о осећањима не сме отворено говорити. У складу са тим, Ташана сестру не пита да ли воли некога, већ да ли је неко њу заволео. Изговоривши бегово име као одговор на сестрино питање, Стојанка изриче његову љубав, али уједно признаје и љубав коју сама према њему осећа. Од сестре, међутим, не добија ни дозволу ни охрабрење. Без обзира на саосећање и разумевање, Ташана сопственим примером опомиње Стојанку и подсећа је да мајчина клетва није намењена само за овоземаљске патње, већ да „прати на онај свет", поручујући сестри да би кршењем забране осигурала своју несрећу и патњу не само на земљи, већ и након смрти.

Пошавши за Турчина, Ташана је направила преступ због којег сада испашта, али она ипак успева да опише сестри и нешто од краткотрајног задовољства које је прелажење границе донело:

Једног дана, на привече падаше киша, после стаде. Затим обасја месечина. Разли се нешто, те човек кад дише а оно му клизи по грудима и обузима га слатка дремљивост. Ми изађосмо на доксат. Вечерасмо, па легосмо. Истина, сестро, да је срамота, али волели смо се (Станковић 2014: 30, курзив А. К.).

Еротско задовољство предочено је и положајем у којем су Ташана и њен муж затечени у ноћи убиства (спавају загрљени), а потврђено у њеним речима: „волели смо се”. Међутим, вече које је створено за сласт еротских уживања претвара се у ноћ у којем Ташана губи и мужа и брата. Није неважна ни чињеница да Ташана у тренутку сукоба стаје на страну свога мужа и покушава да отме брату нож. То је уједно и основни разлог мајчине клетве: она куне јер губи сина, а не само зато што јој се кћерка потурчила. Циљ ове Ташанине приче јесте дидактичка порука, опомена упућена Стојанки да краткотрајна срећа коју је сама доживела ипак није била вредна мајчине клетве и последица које сада мора да подноси. Остаје 
неизвесно да ли би Ташана на исти начин саветовала сестру да јој је муж преживео.

Иако је забрана коју Стојанка осећа изразито јака, она ипак не може да се одупре својој еротској имагинацији и хипнотишућој љубави, која је константо привлачи бегу:

Али јој опет изађе бег. Његов глас, речи... Сва дрхти, гори, боји се. Не сме да мисли на њега. Силом склапа очи, само да га не гледа. Али све он па он!... (Исто: 27).

Забрањено носи велики еротски потенцијал - то је део људске природе. Што више Стојанка брани себи да има било какав однос са бегом, више мисли о њему и њена еротска енергија постаје већа и снажнија. „Унутрашње искуство еротизма тражи од онога ко га доживљава да у истој мери осећа зебњу на којој се темељи забрана и жељу која води њеном гажењу" (Батај 2009: 34). Свест о забрани све више подстиче жељу за њеним кршењем. Пишући о сусрету Маргарите и мајстора у Булгаковљевом роману, Михаил Епштејн (2010: 15) истиче да је у љубавним сусретима често присутно нешто негативно (неки „трн”), што постаје нужно како би се две особе лакше и јаче приближиле једна другој. У том смислу може се говорити и о привлачности између Стојанке и бега - један део те привлачности сасвим сигурно произлази управо из свести о забрани и немогућој љубави. Бежећи од бега, Стојанка бежи од сопствених мисли и од сопствених осећања:

- Турчин, Турчин! Ах, да само то неје! Како да му кажем? Смем ли?!... Где је то било да хришћанка 'оће Турчина? Ax, да 'оће бар силом (Станковић 2014: 27, курзив А. К.).

У вези са овом Станковићевом приповетком, Милан Комненић (1982: 310) истиче да би Стојанка вероватно услишила жељу Шаћир-бега да нема приче њене сестре Ташане, као и да се у њеном узвику „ах да 'оће бар силом" крије садо-мазохистичка црта на којој се гради мотивација приповетке. Забрана коју Стојанка осећа толико је јака да она прижељкује да је бег узме „на силу”. Овај Стојанкин узвик не тумачимо као израз жеље за садо-мазохистичким уживањем, већ као могућност, покушај да саму себе лиши осећања одговорности, у својим очима и у очима других. Када би је бег узео силом, Стојанка не би морала да понесе терет одговорности који прати одлучивање - не би она била та која је починила преступ, не би издала мајку, сестру и сећање на брата, као ни религијску и друштвену заједницу у којој живи. Самим тим била би ослобођена последица које би такав чин донео и вероватно би могла да се препусти еротским чарима таквог поступка. 
Неколико пута у приповеци Стојанка покушава да пронађе начин да се оглуши о забрану и да се препусти еросу, али и да избегне казну. Први покушај огледа се у овом узвику „ах да бар оће силом”, други у разговору са сестром. Поверавајући се Ташани, она узалуд тражи неку потврду од сестре, дозволу или наговештај о томе да је чак и потоња несрећа била вредна. На крају, последњи покушај је разговор са мајком - помињући мајци Ташану, Стојанка посматра њену реакцију у нади да ће можда нешто у њиховом односу моћи да се промени. Када би мајка опростила Ташани, онда би било наде и за њу саму, онда би и она могла да се нада мајчином опроштају и разумевању. Ни ту, међутим, не проналази решење - забрана остаје, а ерос се потискује.

\section{Ослобођени ерос: ноћ, месечина и песма}

Акумулирана еротска енергија, љубавна и сексуална жеља, коју осећају и Стојанка и бег некако се морају испољити. Унутар строго уређене заједнице као што је Станковићево Врање постоје дозвољени начини за изражавање еротског набоја, али се морају испунити одређени услови, типични за Станковићеву поетику. Пре свега јунак се мора налазити у затвореном простору или потпуно сам или са неким ко га не може угрозити; ноћ пуна месечине представља време за буђење ероса, а народна песма коју јунаци певају постаје израз љубавне патње и чежње.

Када Стојанка одлази у посету својој сестри, она плаче у њеном наручју док је Ташана милује по прсима. То миловање није лишено ероса и подсећа на миловања између љубавника:

Таша је десном руком узе за главу, левом за пас и благо је посади у скут. Раскопча јој јелек, разгрну кошуљу, па је поче миловати пред пуним једрим недрима (Станковић 2014: 29, курзив А. К.).

Ова интимна сцена обилује еротским набојем и извучена из контекста могла би представљати увод у сексуални однос између љубавника, па је овакав призор изразито амбивалентан, јер се приповеда о две жене у крвном сродству - две сестре. Нисмо склони, ипак, да у овоме видимо одраз инцестуозног односа између Ташане и Стојанке, већ оваква миловања разумемо као начин експресије нежности и чежње за љубавним додиром, коју обе сестре осећају - једна за умрлим мужем, а друга за забрањеним мушкарцем.

Елементи аутоеротике, призори посматрања, додиривања и миловања сопственог тела, који своју круну добијају са Софком у Нечистој крви, нису изостали ни у овој Станковићевој приповеци. Како би уопште 
дошло до оваквих тренутака, неопходно је да јунакиња буде у затвореном, сигурном простору (далеко од очију заједнице), или потпуно сама или са неким ко је не може угрозити. На тај начин Нушка у истоименој приповеци плеше и увија се у еротској екстази иза зида који је одваја од других, а једини присутан сведок (захваљујући којем се прича о том тренутку и преноси читаоцима) јесте њен рођак, мали дечак; страх од отвореног простора изразито је присутан у приповеци „Покојникова жена”, и овде је он дубоко повезан са дозволом за уживање у затвореном. Новица Петковић (1988: 97) указује на ову значајну везу између тела и простора код Станковића: „Страх од отвореног простора и потискивање тела, и задовољство у затвореном простору и опуштање тела, појава је која се може пратити у многим Станковићевим делима. Она не би била могућа када се у тим делима не би придавао значај прикривеној вези између тела и простора.” Тако је и у приповеци „Стојанке, бела Врањанке” неопходно да се Стојанка повуче у самоћу своје собе како би се препустила својој еротској имагинацији и уживању у сопственом телу:

Стојна пошто свуче шалваре, јелеке, оста само у кошуљи. Затим разгрну широке рукаве кошуље и поче загледати своје пуне, обле руке. Поче се шашољити по врату, плећима и грудима. Подузе је ватра и миље. Срце се разиграло, душа раздрагала, крв угрејала... Својим лепим ручицама стискаше груди.

- Ах, ко ће да стиска и љуби?!

И нехотице изађе јој бег. Његова лепа уста и бели зуби (Станковић 2014: 33-34).

У еротским описима женског тела у овој приповеци посебно место имају управо женске груди: миловања са Ташаном, стискање сопствених груди, замишљање бегових руку на грудима, бегова маштања о Стојниним грудима и снази, мучне мисли о туђим рукама управо на њеним прсима, нож који се забија у груди и на самом крају његове руке на њеном мртвом телу. Груди су симбол женствености и женске сексуалности; ретко који други део женског тела је тако слављен у сликарству и књижевности. Оне представљају непресушни извор фасцинације и незаобилазно место у еротском опису жене, а о томе пише и Михаил Епштејн (2010: 143) у књизи Sola amore: „Груди представљају бескрајан ужитак за додире, зато што се из једне облине рађа друга, из великог брега мали брег, те један можете да утискујете у други или да га истискујете из оног другог. Брадавица штрчи и угиње се, и што је више голицаш, утапајући је у груди, она се оштрије и напрегнутије подиже из груди, горда и непокорна.” Женске груди су израз њеног еротског бића, имају значајну улогу у сексуалном задовољству жене, па су добиле значајно место и у овој Станковићевој приповеци. 
Ноћ је овде, као и у другим Станковићевим делима, време када се буди ерос. То је време најпогодније за сексуално спајање јер тада долази до „преласка свести у седиште срца” (Евола 1990: 107). У ноћи и под светлом месечине шире се мириси и песма као једини дозвољени начин љубавног разговора. „Као што свако општење поседује одговор и обраћање туђем говору, тако и жеља говори са туђим жељама" (Епштејн 2010: 30). Једини начин на који Стојанкина и бегова жеља могу да разговарају међусобно јесте кроз песму, па није чудно што читава приповетка носи наслов по називу песме. То је опште место код Станковића: тако разговарају Цвета и Стојан у приповеци „У ноћи” (преко стихова „Ветар душе, ветар душе, алкатмер мирише/ драги драгој, драги драгој ситну књигу пише” (Станковић 2014: 25), таква је функција песме „развише ружу ветрови” коју Аница замишља у приповеци „Покојникова жена”, па је то случај и са овом Станковићевом приповетком.

Мек, готово нечујан, глас песме и шаркије трже је из заноса. Претрну, повуче се у таму и брзо навуче кошуљу. После пузећи дође до постеље и леже, покривши јорганом главу, само да не слуша песму. Али не мога да одоли, већ промоли главу и поче ослушкивати песму пуну сете, благости и чежње. Шаркија јецаше, а обао и мек глас певаше тихо познату песму:

Стојанке, бела Врањанке!

То беше Шаћир бег (Станковић 2014: 34, курзив А. К.).

Баш у тренутку еротског заноса Стојанка чује песму Шаћир-бега и не могавши да јој одоли - препушта јој се. Бег је песмом и гласом својим милује, а у ноћи преко мелодије преноси се треперење еротског узбуђења, љубавне чежње и туге. Пишући о манифестацијама ероса у источњачкој и западњачкој култури, Милан Комненић (1982: 298) истиче да исток инсистира на мелодији и звуку: „Исток се окреће мелодији, звуку, флуиду, чујности, час камерном, час необузданом и широком сазвучју. Звук наговештава, посредно најављује присуство Ероса.”

Певање кроз ноћ доводи до миловања песмом, јединог дозвољеног миловања. У том смислу и Епштејн (2010: 60) пише о ваздушној еротици, о еротици растојања и преношења еротске енергије кроз ваздушне вибрације. Тако и бегова еротска енергија налази Стојанку у кревету, гласом и песмом Шаћир је милује и она му се ту слободно, без икакве силе, у потпуности предаје.

Песма истовремено представља једини начин сублимације еротског нагона за бега, једини начин на који се његова еротска енергија може испољити, а да никога не угрози. То је једини простор у којем ерос може 
да буде слободан, па отуд не изненађује што управо у песми он опстаје и након Стојанкине смрти.

\section{Сила - преступ забране}

Док Стојанка са своје стране у тишини прижељкује да је Шаћир „уграби на силу”, бег се управо томе опире и на тај поступак самом себи поставља забрану:

Неће га!... А што? Та он би је тако чувао, неговао... Али вера, вера!... Да није коленовић, знао би он. Али овако не може. Силом? Да је уграби, потурчи? Нашто? Једна њена суза, уздах - за њ би био пакао. Она ће га гледати као крвника, господара, Турчина... Истина, биће његова, сва, челцата, имаће тело, али душе, sубави неће имати! (Станковић 2014: 28, курзив А. К). ${ }^{8}$

Када би узео Стојанку против њене воље, бег верује да би то подразумевало само поседовање тела. Испунила би се сексуална потреба, али не би било љубави. Овде је присутно разликовање између физичког и љубавног чина, између чистог сексуалног спајања и еротског спајања. Ако би је узео силом, дошло би до телесног спајања које би донело физиолошко олакшање, али не и уживање, донело би физичко растерећење, али не и испуњење жеље. Разлика између тела и душе о којој бег размишља може се повезати са разликом између сексуалности и еротизма. Говорећи о разлици између сексуалног и еротског, Михаил Епштејн (2010: 25) истиче да сексуално представља примарни, животињски нагон, док еротско подразумева завођење и откривање, константно прелажење постављених граница. Сексуалност има потребу за пражњењем, док еротика не подразумева пражњење, она се „налази у самој жељи која није сводива ни на какав физички акт задовољења" (Исто: 26). Таква је и жеља коју бег осећа према Стојанки - жеља за њеним телом и њеном душом не може се удовољити присилним сексуалним чином. Он жели њу као еротско биће и жели да га она види као мушкарца, а не као крвника или Турчина. „Посебност еротике у поређењу са сексуалношћу је у томе што она није усмерена на тела, већ на туђе жеље” (Исто: 27). Шаћир жели да буде предмет Стојанкине жеље: он жели да га она жели. У овоме се огледа и дијалошка природа и етика ероса: „У томе је етика ероса, која по својој

\footnotetext{
${ }^{8}$ Веома су сугестивне и снажне таутологије до којих долази у мислима јунака: Шаћирова мисао „зажели се ње, ње”, Стојанкино „Турчин, Турчин” и на крају бегово „вера, вера” сликовито представљају основна тежишта на којима се гради радња приповетке - забрана, ерос и танатос.
} 
суштини искључује присилу. Присила је еротична у оном смислу у коме буди жељу, а не дејствује упркос њој” (Исто: 29).

О беговој љубави сведоче његове речи и његови поступци: у разговору он истиче да не жели Стојанкину веру и води рачуна о томе када и где је среће, на који начин јој се обраћа како је случајно не би погледом или речју компромитовао или увредио. Претерана учтивост у односу са Стојанком указују на забрану, која није само колективна. Љубав коју Шаћир према Стојанки осећа временом постаје јавна тајна и читава заједница само ишчекује вест о томе да ју је бег отео. Шаћир, међутим, упорно одбија такву могућност. Он сам то себи не дозвољава иако је то нешто што сви, па и Стојанка очекују.

Иако сасвим сигурно не жели да повреди Стојанку, његов ерос храни њен дрхтави глас: „Бега од овог дрхтавог звонког гласа подузе нека милина и раздраганост” (Станковић 2014: 25); и „У ушима му затрепта њен благи, молећиви глас" (Исто: 28). Он чува невиност њеног бића као нешто најсветије, јер га управо та невиност највише привлачи и узбуђује, али истовремено се његова еротска имагинација храни тиме што јој се прикрада под прозоре у време кад се она пресвлачи и спрема за спавање.

Не заборавимо да је бег особа која има моћ, што се види већ на самом почетку приповетке у опису његовог сераја. Познато је да је простор увек повезан са јунаком код Станковића, па је то случај и у овој приповеци. Изузетност бића дочарава се и кроз опис простора у којем он обитава:

Опасан високим зидовима, витким тополама а прекривен ладолежом и другим дрвећем, истицаше се јасно из овог зеленила са својим терасама и доксатима. Беше окренут Ковачкој маали, која се у густом зеленилу од дудова, ораха, црешња и кајсија, једва познаваше са својим малим приземним кућицама, црним угнутим крововима, а по гдегде и којом сламаром (Исто: 23, курзив А. К.).

Сама позиција беговог сераја таква је да он може све да види, али њега не могу да виде јер увек може да се повуче иза високих зидина - он је јунак који има моћ, али је он у Стојанкиној моћи. Шаћир одбија да своју моћ употреби против ње и на све начине настоји да избегне преступ сексуалне забране, који заиста до краја приповетке неће починити. Зато ће прегазити другу границу и оглушити се о другу врсту забране, забрану против насиља. Од некога ко не жели на силу да отме девојку (која управо то у самоћи прижељкује) бег ће постати убица, а чесма као место љубавног састанка претвориће се у место злочина. ${ }^{9}$

\footnotetext{
${ }^{9}$ Овакав расплет наговештава се од самог почетка приповетке кроз постављене разлике, потиснути ерос, па и само место састанка. Чесма је сигурно и дозвољено место сусрета јер представља јавни простор доступан свима, а налази се на пола пута и из вароши и од сераја,
} 
Неостварена и акумулирана еротска енергија враћа се на бега и гуши га. Док посматра Стојанку њега обузимају „тешке и грешне мисли”, а ту је и уздах „изеде ме!” који илустративно указује на његово психичко стање и јачину ероса која га притиска. Његова жеља и љубав очајнички траже одговор и задовољење: „Да ми р'з даје, клеко би', плакао, молио, док се не смилујеш, те се насмејеш и прозбориш слатку, убаву реч" (Станковић 2014: 26). При томе, Шаћир је све време свестан амбиса који их раздваја и слути несрећу која се око њих обавија: „Дође му тешко. У грудима му се разли нека туга помешана страхом. Пред њиме зину амбис који их раздваја" (Исто: 28).

Чини се да бег успева на неко време да контролише своју љубавну чежњу, али до кулминације долази када чује да је Стојанка испрошена за другог. Посесивност и љубомора које неизбежно прате еротску жељу, бега доводе до лудила и наводе га да се оглуши о забрану против насиља. Као један од најбитнијих елемената сваке љубавне везе, Јулијус Евола (1990: 38) издваја управо опсесивну обузетост другим у мислима: „мисао једног обузета је, мање или више опсесивно другим, у облику делимичне схизофреније.” Поседовање јесте оно што разликује сексуалну љубав од љубави уопште (Исто: 115), а у складу са овим је и бегова мисао након убиства - „Ако! Кад не моја, онда ничија” (Станковић 2014: 37). Сама помисао да други поседује вољену особу, замишљање туђих руку на телу вољене представљају једно од општих места еротизма. Тако и бег замишља грубе руке Стојниног вереника на њеном телу и те слике га прогањају, а заједно са њима развијају се мисли о недостојности тих руку: „Испросио је њен комшија, неки младић, ужар. Он? Зар његове грубе руке да стискају њу? Њену снагу која би се при даху растопила...” (Исто: 35-36, курзив А. К.).

Мисао да њу нико други не заслужује јер је нико други није достојан сведочи о егоизму, па и нарцисоидности, која често представља саставни део ероса. Бегу се чини да само он може и сме имати Стојанку. У његовим мислима она је већ била његова, па зато тако болно доживљава могућност туђих миловања. Опис љубоморе и беса који Шаћир осећа када се сусретне са Стојанком након вести о њеној удаји подсећа на дескрипцију еротског узбуђења и сведочи о опасној граници којој се бег приближио: „Очи му закрвављене, уста се раширила и играју. Груди брекћу, мислиш е сад ће

па симболички може представљати покушај превазилажења разлика које раздвајају бега и Стојанку. С друге стране, то је место повезано са водом, изразито женским принципом, па је и на тај начин у вези са манифестацијом ероса у овој приповеци. На крају, чесма може подсећати и на функцију бунара у фолклору, који је увек повезан са демонским силама и силаском у доњи свет (Радуловић 2009: 43), што указује на мрачну природу догађаја који ће се ту одиграти. 
прснути" (Исто: 37). Реч која изазива коначно помрачење свести код бега јесте Стојанкина реч да је он „крвав” и „Турчин”. Изговоривши ове речи, она чини да се обистине његови страхови јер потврђује да га види као насилника, што је судбина којој се он од почетка свим снагама опирао. Тада се бег први пут у потпуности препушта нагону, па је убиство неизбежно.

Пишући о садо-мазохистичким странама еротизма, Жорж Батај (2009: 36) истиче да је порив љубави, колико год то изгледало парадоксално, повезан са поривом смрти. Сам чин убиства у овој приповеци описан је слично љубавном чину. Први и једини пут када бег држи Стојанку у наручју јесте у тренутку у којем је убија:

Крвав, крвав?!... Ја, ја? - викаше, крчаше, вртеше се с њом. Њена крв свога га попрска и умрља. Очи закрвавиле, па се готово преврнуле. Коса уздигнута. Уста сва у пеки. Упрљан крвљу, по лицу, грудима... Вртеше се као луд, вичући тмулим и крештавим гласом: - Ја, ја?... Крвав, крвав? (Станковић 2014: 37, курзив А. К).

Уздигнута коса, узвици и уздаси, преврнуте очи подсећају на сексуалну екстазу и доживљај оргазма. „Оргазам и представља заправо инфаркт андрогина, његову скору смрт и разбијање на два леша, који се само постепено могу освестити у односу на свој раздвојени живот" (Епштејн 2010: 74). Од фигуративног крвав си ми у значењу „крвник си ми”, бег постаје и буквално крвав. Упрљаност њеном крвљу може бити алузија на изгубљену невиност и на крв током првог сексуалног односа. Пишући о роману Нечиста крв, Новица Петковић (1988: 29) истиче да је повезивање еротског са гробљанским честа појава код Станковића, што се може објаснити преко фолклорног повезивања „љубавног заноса и смртног издисаја." Код Станковића јунаци често замишљају како би изгледао сексуални однос са вољеним бићем. Овде ако није могао да је има живу, бег ће имати Стојанку мртву и у самом чину убиства он ради оно што би радио у сексуалном чином. ${ }^{10}$ Након што тренутно помрачење свести пролази, бег постаје свестан свог поступка, спушта Стојанкино тело, откривајући и љубећи нежно груди за којима је толико чезнуо.

Огромна је моћ ероса: то је животворна енергија, која може учинити да се „срце разгали, свет размирише и јело услади” (Станковић 2014:

${ }^{10}$ Визуелна представа смртног загрљаја као загрљаја страсних љубавника архетипска је и подсећа на мит о Ахилеју и Пентесилеји. У току тројанског рата Ахилеј убија Пентесилеју, краљицу Амазонки и кћерку Арејеву и Отрерину, пробијајући мачем њене груди, али у том часу постаје свестан њене лепоте и заљубљује се у њу (Срејовић 1979: 333). Веза између љубавног заноса и смртног загрљаја присутна је у различитим видовима у културама широм света. Овакве приче, легенде и митови сведоче о дубљој вези између ероса и танатоса, а то долази до изражаја и у овој Станковићевој приповеци. 
26). Ерос даје сласт храни, мирисе и укусе свету - живот чини вредним живљења, а човеку омогућује да се осећа живим. То знају и јунаци ове приповетке и зато не могу да га се одрекну, а истовремено покушавају да га потисну јер стрепе од кршења установљених забрана. Крећући се константно између забране и ероса, они су од почетка осуђени на пропаст. Забране које осећају нису само колективне, већ и интимне, па оглушење о њих доводи до унутрашњих сукоба. Потискивање ероса постаје погубно за обоје и бега тера у лудило, а Стојанку у смрт. Неостварени ерос ипак остаје да живи као Шаћирова љубавна патња и бива заувек очуван у његовој тужној песми.

\section{ИЗВОРИ И ЛИТЕРАТУРА}

Андрић 1981: И. Андрић, Јелена, жена које нема, Сарајево: Свјетлост. Батај 2009: Ж. Батај, Еротизам, Београд: Службени гласник.

Евола 1990: J. Евола, Метафизика секса I, Чачак: Дом културе Чачак.

Епштејн 2010: М. Епштејн, Sola amore, Београд: Центар за медије и комуникације.

Комненић 1982: М. Комненић, Ерос и искуство крајности, у: М. Комненић (прир.), Горопадни ерос, Београд: Просвета, стр. 281-320.

Пас 1982: О. Пас, Еротизам и сексуалност, у: М. Комненић (прир.), Горопадни ерос, Београд: Просвета, стр. 60-65.

Петковић 1988: Н. Петковић, Два српска романа, Београд: Народна књига.

Радуловић 2009: Н. Радуловић, Слика света у српским народним бајкама, Београд: Институт за књижевност и уметност.

Срејовић 1979: Д. Срејовић, Александрина Цермановић Кузмановић, Речник грчке и римске митологије, Београд: Српска књижевна задруга.

Станковић 2004: Б. Станковић, Нечиста крв, Београд: Народна књига: Политика.

Станковић 2014: Б. Станковић, Из мога краја, Ниш: Талија издаваштво.

Станковић 2014: Б. Станковић, Стари дани - Божји људи, Ниш: Талија издаваштво. 
Ana D. Kozić

THE FORBIDDEN AND THE EROTIC IN THE STORY „STOJANKE, BELA VRANJANKE”BY BORISAV STANKOVIĆ

\section{Summary}

The paper researches the complex and dynamic relationship between prohibition and eros, between the forbidden and the erotic in the story „Stojanke, bela Vranjanke”, considering also the characterization of the main characters in this narrative. Special emphasis is laid on the interpretation of the artistic means, which introduce, describe and manifest the erotic in literature.

Key words: prohibition, erotic, thanatos, Borisav Stanković. 